Cornell University Law School

Scholarship@Cornell Law: A Digital Repository

Spring 2017

\title{
The Supreme Court's Application of'Ordinary Contract Principles' to the Issue of the Duration of Retiree Healthcare Benefits: Perpetuating the Interpretation/Gap-Filling Quagmire
}

Robert A. Hillman

Cornell Law School, rah16@cornell.edu

Follow this and additional works at: http://scholarship.law.cornell.edu/facpub

Part of the Contracts Commons, and the Labor and Employment Law Commons

\section{Recommended Citation}

Hillman, Robert A., "The Supreme Court's Application of 'Ordinary Contract Principles' to the Issue of the Duration of Retiree Healthcare Benefits: Perpetuating the Interpretation/Gap-Filling Quagmire," 32 ABA Journal of Labor \& Employment Law 299 (2017) 


\title{
The Supreme Court's Application of "Ordinary Contract Principles" to the Issue of the Duration of Retiree $\mathbb{H e a l t h c a r e}$ Benefits: Perpetuating the Interpretation/Gap-Filling Quagmire
}

\author{
Robert A. Hillman*
}

\section{Introduction}

The U.S. Supreme Court purported to apply "ordinary contract principles" in reversing the Sixth Circuit in $M \& G$ Polymers USA, L.L.C. v. Tackett. ${ }^{1}$ The Sixth Circuit had held that plaintiffs, retired M \& G employees, were entitled to lifetime healthcare benefits under their union's Pension, Insurance, and Service Award Agreement (hereinafter P\&I agreement). ${ }^{2}$ Justice Clarence Thomas, writing for a unanimous Court, concluded the Sixth Circuit had relied on a false set of "inferences" established in International Union $v$. Yard-Man, Inc. ${ }^{3}$ to find that "in the absence of extrinsic evidence to the contrary, the provisions of [the collective bargaining agreement] indicated an intent to vest retirees with lifetime benefits." The Supreme Court therefore re-

* Robert A. Hillman is the Edwin H. Woodruff Professor of Law at Cornell Law School. Professor Hillman has written extensively on contracts and contract theory, the Uniform Commercial Code, and employment law. Professor Hillman thanks Kevin Clermont, David Hoffman, and Stewart Schwab for reading and commenting on this Article.

1. 135 S. Ct. 926 (2015) (hereinafter $M \& G$ ). At oral argument, Justice Sonia Sotomayor introduced the phrase "ordinary contract principles." Questioning the petitioner, she said, "You're recommending we apply ordinary contract principles, no?" Transcript of Oral Argument at 4, $M \& G, 135$ S. Ct. 926 (No. 13-1010).

2. The plaintiffs represented a class of retired union workers from $M \&$ G's Point Pleasant Polyester Plant. They alleged violations of section 301(a) of the Labor Management Relations Act of 1947, 29 U.S.C. $\$ 185$ (a), as well as section 502(a)(1)(B) and section 502(a)(3) of the Employee Retirement Income Security Act of 1974, 29 U.S.C. $\S \S 1132(\mathrm{a})(1)(\mathrm{B})$, 1132(a)(3). "To vest, in this context, means to remain binding beyond the expiration of the collective bargaining agreement.'” Tackett v. M \& G Polymers USA, L.L.C. 733 F.3d 589, 596 (6th Cir. 2013) (hereinafter Tackett II).

3. 716 F.2d 1476 (6th Cir. 1983) (hereinafter Yard-Man).

4. $M \& G, 135 \mathrm{~S}$. Ct. at 933. 
manded the case, instructing the lower court to disregard the inferences and to apply "ordinary contract principles" to determine the parties' intentions with respect to the duration of retiree healthcare benefits. ${ }^{5}$

The Court's decision to remand was correct, but its discussion and application of "ordinary contract principles" was quite amateurish. The concurrence's analysis was better, but left unclear the appropriate judicial approach to ambiguity or omission in a contract. ${ }^{6}$ Unfortunately, the decision caused uncertainty about what evidence may be considered in similar cases, including cases that go beyond the collective bargaining context.

This Article documents the Supreme Court's errors in applying "ordinary contract principles." In doing so, the Article suggests how courts should proceed in contract cases like $M \& G$. Specifically, in applying "ordinary contract principles," the Court should have treated the "Yard-Man inferences"7 as probative, along with all other evidence concerning the duration of healthcare benefits. Further, the Court should have framed the inquiry as first seeking to determine a reasonable interpretation of the P\&I on the duration issue, instead of fixating on the "parties' intentions," which led the Court down the wrong path. Ultimately, the Court should have instructed the lower court that if the trier of fact could not determine the duration of healthcare benefits based on a reasonable interpretation of the agreement and circumstances, the court should fill the gap from available contract-law gap fillers. This approach would free future courts from the unhelpful detour of trying to find the "intention of the parties" when, as we shall see in $M \& G$, the parties never reached agreement on the duration issue. This roadmap would have avoided the Supreme Court's repudiation of the "Yard-Man inferences," as if they were not an application of "ordinary contracts principles."

\section{Yard-Man and $M \& G$}

A. International Union v. Yard-Man, Inc.

Under the Employee Retirement Income Security Act (ERISA), which in part governs pension and welfare benefits under collective bargaining agreements (CBA), healthcare benefits, unlike pensions, do not automatically vest. ${ }^{10}$ Instead, the duration of benefits depends on the terms of the collective bargaining agreement. ${ }^{11}$ In Yard-Man,

5. Id.

6. Justice Ruth Bader Ginsburg wrote the concurring opinion, joined by Justices Stephen Breyer, Sonia Sotomayor, and Elena Kagan. Id. at 937 (Ginsburg, J., concurring).

7. $M \& G, 135 \mathrm{~S}$. Ct. at 933 .

8. Id.

9. See infra Part II.

10. 29 U.S.C. $\$ 1051(1)(2012) ; M \& G, 135$ S. Ct. at 933 . Under ERISA, the contract determines when a pension vests. $I d$.

11. 29 U.S.C. $\S 1102(a)(1)$. 
the Sixth Circuit analyzed whether the employer breached the CBA by terminating retiree healthcare benefits. ${ }^{12}$

The Sixth Circuit affirmed the trial court's determination that the CBA at issue guaranteed lifelong health retiree benefits (but reversed on other grounds). ${ }^{13}$ The court relied on "basic principles of contractual interpretation" to determine the "parties' intent." 14 The court identified a helpful hierarchy of relevant factors:

[T] he court should first look to the explicit language of the collective bargaining agreement for clear manifestations of intent. The intended meaning of even the most explicit language can, of course, only be understood in light of the context which gave rise to its inclusion. The court should also interpret each provision in question as part of the integrated whole. If possible, each provision should be construed consistently with the entire document and the relative positions and purposes of the parties. As in all contracts, the collective bargaining agreement's terms must be construed so as to render none nugatory and avoid illusory promises. Where ambiguities exist, the court may look to other words and phrases in the collective bargaining agreement for guidance. Variations in language used in other durational provisions of the agreement may, for example, provide inferences of intent useful in clarifying a provision whose intended duration is ambiguous. [T] he interpretation rendered [should] not denigrate or contradict basic principles of federal labor law. ${ }^{15}$

The Sixth Circuit then applied this framework. ${ }^{16}$ First, it identified pertinent language of the agreement, "[t]he Company will provide insurance benefits equal to the active group benefits ... for the former employee and his spouse," but found that the language was ambiguous because it could have referred to the nature of retiree benefits or could have incorporated "some durational limitation as well."17 The court then turned to the rest of the CBA for guidance. ${ }^{18}$ The CBA expressly set forth a termination schedule for active employees' benefits. ${ }^{19}$ But these were "under conditions-the layoff of seniority employeestypically inapplicable to retirees." 20 In addition, variations in the duration of active employee healthcare benefits based on seniority made it unlikely that retiree benefits depended on "the fortunes of active em-

12. 716 F.2d 1476, 1478 (6th Cir. 1983).

13. Id.

14. Id. at 1479 .

15. Id. at 1479-80 (internal citation omitted). The applicable law is the general "federal labor law." Gregory Parker Rogers, Rethinking Yard-Man: A Return to Fundamental Contract Principles in Retiree.Benefits Litigation, 37 Emory L.J. 1033, 1041 (1988).

16. Yard-Man, 716 F.2d at 1480 .

17. $I d$.

18. Id.

19. Id. at 1481 .

20. $I d$. 
ployees."21 Further, Yard-Man continued to pay benefits to retirees beyond when they could have been discontinued for active employees, "indicat[ing] that it did not consider retiree benefits to be tied to the durational limitations of that active group." 22

Upon retirees' deaths, the CBA also limited health insurance for the retirees' immediate families to the duration of the collective bargaining agreement, suggesting that retiree healthcare benefits, silent on duration, should be treated differently. ${ }^{23}$ Further, the agreement included many specific additional limits on duration, including one dealing with "savings and pension plan programs." ${ }^{24}$ The court reasoned that the absence of a specific duration clause for retiree health insurance benefits suggested that the parties had different intentions with respect to their duration, specifically that they vested upon retirement. ${ }^{25}$ The Sixth Circuit was not troubled by the CBA's "routine duration clause" of three years in the CBA that, because of its generality, did not trump the other more specific evidence of intent. ${ }^{26}$

Perhaps most persuasive to the Yard-Man court, and a highly contentious issue in the Supreme Court, was that healthcare benefits were "permissive [and] not mandatory subjects of collective bargaining."27 The court believed such delayed compensation ordinarily would not be left for future negotiation. ${ }^{28}$ In a revealing passage, the court inferred that retirees likely traded current compensation for vested insurance benefits-"If [retirees] forego wages now in expectation of retiree benefits, they would want assurance that once they retire they will continue to receive such benefits regardless of the bargain reached in subsequent agreements." 29

Some of the Sixth Circuit's arguments seem less persuasive. ${ }^{30}$ However, Yard-Man generally gives the impression that the accumula-

21. $I d$.

22. $I d$.

23. Id.

24. Id. at $1481-82$.

25. Id. at $1482-83$.

26. $I d$.

27. Id. at 1482. "Although ERISA imposes elaborate minimum funding and vesting standards for pension plans, it explicitly exempts welfare benefits plans from those rules." $M \& G, 135$ S. Ct. at 933; see also Allied Chem. \& Alkali Workers of Am., Local Union No. 1 v. Pittsburgh Glass, 404 U.S. 157, 180 (1971) (retiree benefits not mandatory bargaining subject).

28. Yard-Man, 716 F.2d at 1482.

29. Id.

30. For example, the court reasoned that the promise of healthcare benefits when an employee turned sixty-five would be illusory for early retirees between the age of fiftyfive and sixty-two because the CBA containing this promise lasted only three years. Id. at 1481 . True, the promise would be worthless to early retirees, but as the Supreme Court pointed out, the promise was not illusory for employees who retire at sixty-five. A "promise that is "partly' illusory is by definition not illusory." $M \& G, 135 \mathrm{~S}$. Ct. at 936 . 
tion of CBA factors persuaded the court that the parties intended to vest the retirees' insurance benefits.

B. M \& G Polymers USA v. Tackett in the Lower Courts

1. Tackett v. $M$ \& G Polymers, USA, L.L.C. (Tackett I) ${ }^{31}$

$M$ \& G purchased a polyester plant in 2000 and entered into a CBA and P\&I agreement with the employees' union. ${ }^{32}$ When $\mathrm{M} \& \mathrm{G}$ began to require employees to contribute toward their healthcare benefits, Tackett and other retirees representing a class of retired workers, along with the union, sued, claiming that the P\&I agreement guaranteed them lifetime contribution-free healthcare benefits. ${ }^{33}$ The disputed P\&I language stated:

Employees who retire on or after January 1, 1996 and who are eligible for and receiving a monthly pension under the 1993 Pension Plan ... whose full years of attained age and full years of attained continuous service ... at the time of retirement equals 95 or more points will receive a full Company contribution towards the cost of [healthcare] benefits described in . . Exhibit B-1 . . . Employees who have less than 95 points at the time of retirement will receive a reduced Company contribution. ${ }^{34}$

Exhibit B-1 described the disputed healthcare benefits with this introductory language: "Effective January 1, 1998, and for the duration of this Agreement thereafter, the Employer will provide the following program of hospital benefits, hospital-medical benefits, surgical benefits and prescription drug benefits for eligible employees and their dependents ...."35

M \& G moved to dismiss the complaint, alleging in part that the P\&I agreement did not confer lifetime contribution-free healthcare benefits. ${ }^{36} \mathrm{M} \& \mathrm{G}$ offered evidence of "side letter agreements" that it claimed were incorporated into the P\&I agreement to cap M \& G's contribution to the cost of the benefits. ${ }^{37}$ The district court held that "the 'full Company contribution' language did not plausibly state a claim for vested health care benefits." 38

31. 561 F.3d 478 (6th Cir. 2009) (hereinafter Tackett $I$ ).

32. The union was United Steel, Paper and Forestry, Rubber, Manufacturing, Energy, Allied Industrial and Service Workers International Union, AFL-CIO-CLC. Id. at 480. The plaintiffs alleged violations of section 301 of the Labor Management Relations Act of 1947, 29 U.S.C. $\S 185(\mathrm{a})$, and section 502(a)(1)(B) of the Employee Retirement Income Security Act of 1974,29 U.S.C. $\$ \S 1132(\mathrm{a})(1)(\mathrm{B})$. Tackett 1,561 F.3d at 481.

33. Id.

34. Id. at 482 .

35. $M \& G, 135 \mathrm{~S}$. Ct. at 931 .

36. Tackett $I, 561$ F.3d at 482 .

37. $I d$.

38. Id. at 483 . 
The Court of Appeals disagreed ${ }^{39}$ In testing the sufficiency of the Tackett complaint, the Sixth Circuit stated that it would "appl[y] the principles first described" in Yard-Man and set forth the Yard-Man framework of evaluating the CBA's "explicit language" and, if ambiguous, "extrinsic evidence," each pertaining to the duration of healthcare benefits. ${ }^{40}$ Having implicitly concluded that the P\&I agreement was ambiguous, ${ }^{41}$ the court examined additional relevant language of the agreement for guidance. ${ }^{42}$ Specifically, the court reasoned that the "limiting language," which required employees to contribute to their health benefits if they had insufficient seniority points to qualify for "a full Company contribution," meant employees who had sufficient points would receive lifetime benefits. ${ }^{43}$ Further, the court stated that, because pension benefits vest under ERISA, "[1]anguage in a collective bargaining agreement that 'equate[es] eligibility for retiree health benefits with eligibility for a pension' suggests an intent to vest." 44

The court also relied on the context of the P\&I agreement bargaining: " $[\mathrm{B}]$ ecause retirement health care benefits are not mandatory or required to be included in an agreement, and because they are 'typically understood as a form of delayed compensation or reward for past services' it is unlikely that they would be 'left to the contingencies of future negotiations." 45 Relying on Yard-Man, the court found it "unlikely that [the union] would agree to language that ensures its members a 'full Company contribution,' if the company could unilaterally change the level of contribution."46

The court further reasoned that the applicability of the side letters was a fact issue to be decided at trial. ${ }^{47}$ The court concluded that the complaint was "plausible" and not subject to dismissal. ${ }^{48}$ One can see that Tackett I relied on the earlier Yard-Man roadmap of contract interpretation, but this was far from the end of the saga.

39. Id. at 490 .

40. Id. at 489 .

41. "The qualifying language in Tackett I implied that the CBA language, though indicating intent to vest, contained enough ambiguity to permit examination of such additional evidence." Tackett v. M \& G Polymers USA, 733 F.3d 589, 600 (6th Cir. 2013). The Sixth Circuit in Tackett I disagreed with the district court on the meaning of "full Company contribution." Tackett I, 561 F.3d at 490. The trial court had treated the language as a "potential contribution," but the Sixth Circuit stated that the language "suggests that the parties intended the employer to cover the full cost of health-care benefits for those employees meeting the age and term-of-service requirements." Id.

42. Tackett $I, 561$ F.3d at 490 .

43. $I d$.

44. Id. at 489 (quoting McCoy v. Meridian Auto. Sys., Inc., 390 F.3d 417, 421 (6th Cir. 2004)).

45. Id. (quoting Yolton v. El Paso Tenn. Pipeline Co., 435 F.3d 571, 580 (6th Cir. 2006) (quoting Int'l Union v. Yard-Man, Inc, 716 F.2d 1476, 1481-82 (6th Cir. 1983))).

46. Id. at 490 .

47. Id. at 482 n.1.

48. Id. at 490 . 


\section{Tackett v. $M \&$ \& Polymers, USA, L.L.C. (Tackett II) ${ }^{49}$}

On remand from Tackett $I$, the district court declined to revisit the vesting issue, assuming it had been decided by Tackett I. The court granted a permanent injunction ordering that the plaintiffs receive retiree healthcare benefits for life ${ }^{50} \mathrm{M} \& \mathrm{G}$ appealed, alleging two errors. ${ }^{51}$ First, the trial court should have found that the side letters requiring contributions and capping benefits (and other like documents) were part of the P\&I agreement. ${ }^{52}$ Second, even without the letters, the P\&I agreement did not grant retirees lifetime benefits. ${ }^{53}$

The Sixth Circuit in Tackett II affirmed the trial court's decision that the side letters were not part of the agreement, largely because "several parties with authority to bind $M \& G$ and the union rejected or disputed [the side] letter[s'] applicability." ${ }^{\text {"54 }}$ The trial court erred, however, according to Tackett II, in relying too heavily on one sentence in Tackett $I$ to find that the decision conclusively decided the vesting issue. ${ }^{55}$ The Sixth Circuit wrote in Tackett $I$ that "[t]he determination. . . that the parties intended health care benefits to vest carries over to the ERISA . . claim." ${ }^{56}$ In Tackett II, however, the Sixth Circuit explained that it had not decided the vesting issue based on a "complete factual record" and that "Tackett I did not conclusively determine that Plaintiffs' retirement benefits had vested."57

This Article need not analyze whether the side letters should have been considered part of the P\&I agreement. ${ }^{58}$ Nevertheless, they are relevant to the issue of whether the retirees were guaranteed lifetime healthcare benefits. ${ }^{59}$ An argument that did not surface clearly at any level of litigation was whether M \& G's insistence that the side letters capped the plaintiffs' healthcare rights showed that $M \& G$ did not believe the P\&I agreement alone reasonably could be read to cap benefits. At best, the side letters showed that $M$ \& $G$ wanted to cap benefits, but the finding that the letters did not become part of the agreement suggests that $M \& G$ failed to achieve that goal.

49. 733 F.3d 589 (6th Cir. 2013).

50. The district court's injunction restored the benefits based on the "current versions of the benefits plans they were enrolled in until 2007." The plaintiffs crossappealed and sought benefits based on the pre-2007 agreement. Id. at 592-93.

51. Id. at 592 .

52. Id.

53. Id.

54. Id. at 598. See infra notes 58, 197-99, and accompanying text for further discussion of side letters.

55. Id. at 596-97. (Tackett I).

56. Tackett v. M \& G Polymers, USA, L.L.C., 561 F.3d 478, 491 (6th Cir. 2009)

57. Tackett $I I, 733$ F.3d at 596-97.

58. "The letters were not reproduced in P\&I booklets and allegedly not ratified as part of the local agreement." Id. at 595.

59. $I d$. at 598-99. 
At any rate, in determining the P\&I agreement's meaning, Tackett II confirmed the Sixth Circuit's earlier view that the "full contribution" language of the P\&I agreement "indicated an intent to vest." 60 Because the language's meaning was ambiguous, however, the court entertained extrinsic evidence. ${ }^{61}$ Ultimately, because of trial testimony, the linkage between healthcare benefits and pension benefits, the reasoning of Tackett I, and M \& G's failure to provide evidence to rebut the "full contribution" language, ${ }^{62}$ the court affirmed the trial court's vesting decision and granted a permanent injunction in favor of the plaintiffs. ${ }^{63}$

Nonetheless, Tackett II denied the plaintiffs cross-appeal with respect to the injunction's scope. ${ }^{64}$ The plaintiffs had asserted that the trial court erred when it "ordered retirees and dependents previously enrolled in the pre-2007" plan to receive benefits under the 2007 plan that contained "increased prescription drug costs and annual deductibles." ${ }^{65}$ Following precedent, ${ }^{66}$ the court limited vested benefits by allowing "reasonable changes" to accommodate increased costs. ${ }^{67}$ One can only think that the "reasonable changes" declaration was the court's attempt to craft a compromise, but more on this later. ${ }^{68}$

\section{M \& G Polymers USA, L.L.C. v. Tackett ( $M$ \& $G$ in the}

Supreme Court) ${ }^{69}$

M \& G took Tackett II to the Supreme Court. ${ }^{70}$ In a unanimous opinion written by Justice Clarence Thomas, with Justices Ruth Ginsburg, Stephen Breyer, Sonia Sotomayor, and Elena Kagan concurring, the Court first stated it would apply "ordinary principles of contract law" consistent with federal labor policy. ${ }^{71}$ The Court then indicated it would look to the "parties' intentions" and the "plainly expressed intent" of the agreement as the appropriate "ordinary principles."

The Court foreshadowed its decision by criticizing the Sixth Circuit for "appl[ying] the Yard-Man inferences to conclude that, in the absence of extrinsic evidence to the contrary, the provisions of the con-

60. Id. at 600 .

61. Id.

62. Id.

63. Id.

64. Id. at 601 .

65. Id. at $600-01$.

66. Reese v. CNH Am. L.L.C., 574 F.3d 315, 326 (6th Cir. 2009).

67. Tackett II, 733 F.3d at 601.

68. See infra notes $180-89$ and accompanying text.

69. 135 S. Ct. 926 (2015).

70. Id. at 930 .

71. Id. at 933 .

72. Id. The Court also stated: "Where the words of a contract in writing are clear and unambiguous, its meaning is to be ascertained in accordance with its plainly expressed intent." Id. (citing 11 SAMuEL WILLISTON \& Richard R. LORD, WILLISTON ON CONTRACTS $\S 30: 6$, Westlaw (4th ed. Database updated May 2016)). 
tract indicated an intent to vest retirees with lifetime benefits." ${ }^{73}$ In fact, those "inferences," according to the Court, were not "ordinary principles of contract law" 74 and the Court rejected them. ${ }^{75}$

The Court elaborated. First, the Court accused Yard-Man and its progeny of "placing a thumb on the scale in favor of vested retiree benefits in all collective-bargaining agreements. ${ }^{n 6}$ The Court found the Sixth Circuit's reliance on the context of collective bargaining agreements was "too speculative" and was derived from the court's "own suppositions" instead of the record. ${ }^{77}$ Such speculations "distort[ed] the attempt to "ascertain the intention of the parties." 78 Instead, the Sixth Circuit should have looked to the record for proof of "customs or usages." ${ }^{\text {T9 }}$ To demonstrate an example of Yard-Man's trip down the wrong path, the Court singled out the Sixth Circuit's "supposition[" that "when ... parties contract for benefits which accrue upon achievement of retiree status, there is an inference that the parties likely intended those benefits to continue as long as the beneficiary remains a retiree." 80

Second, the Court said that Yard-Man "rest[ed] on a shaky factual foundation" in categorizing healthcare benefits as deferred compensation. ${ }^{81}$ Without elaboration, the Court reasoned that ERISA healthcare benefits are "welfare plans" and "Congress specifically defined plans that 'resul[t] in a deferral of income by employees' as pension plans ...."82

Third, the Court criticized Yard-Man for discounting "general durational clauses" and especially criticized later Sixth Circuit cases that, according to the Court, created a default rule of vested healthcare benefits. ${ }^{83}$ The Court thought that such an approach conflicted with the presumption that the written agreement constituted the entire agreement. ${ }^{84}$

Fourth, the Court articulated what it identified as relevant "traditional" contract principles that shed better light on the Court's goal of determining the parties' intentions. ${ }^{85}$ For example, the Court ex-

73. Id.

74. Id.

75. Id. at 937.

76. $I d$. at 935. For a discussion of the many cases leading up to Yard-Man and beyond, see Rogers, supra note 15.

77. $M \& G, 135 \mathrm{~S}$. Ct. at 935 .

78. Id. (quoting WILISTON ON ConTRACTS $\$ 30: 2$, supra note 72).

79. Id.

80. Id. (quoting Int'l Union v. Yard-Man, Inc, 716 F.2d 1476, 1482 (6th Cir. 1983)).

81. Id. at 936 .

82. Id.

83. Id.

84. Id. For a discussion of inferences and presumptions, see infra notes $100-09$ and accompanying text.

85. Id. at 936-37. 
plained that ambiguous writings do not create lifetime promises, and promises silent on duration "will ordinarily be treated ... as 'operative for a reasonable time.'" 86 Further, contractual obligations cease when the contract terminates. ${ }^{87}$ Perhaps overly influenced by these "principles," the Court then went so far as to volunteer that absent "explicit terms . . . when a contract is silent as to the duration of retiree benefits, a court may not infer that the parties intended those benefits to vest for life." 88 This language seemingly precluded plaintiffs from defeating a summary judgment motion regardless of the circumstances.

The Court then concluded that the Sixth Circuit in Tackett $I$ and II based its decision largely on Yard-Man and its progeny ${ }^{89}$ and remanded the case to the Sixth Circuit to review the duration issue without reliance on the Yard-Man inferences. ${ }^{90}$ The Court singled out the Sixth Circuit's misdirected focus on context and the likelihood that the union "would not have agreed to language ensuring its members a 'full Company contribution' if the company could change the level of that contribution." 11 By ruling out the use of Yard-Man inferences to prove the parties intended benefits to last for life, the Court created a bit of a mystery on what the Sixth Circuit was to do on remand to review the case "under the correct legal principles."

Justice Ginsburg wrote the concurrence joined by Justices Breyer, Sotomayor, and Kagan. ${ }^{93}$ The concurrence also directed the Sixth Circuit on remand to search for the "intention of the parties." ${ }^{44}$ However, the concurrence recognized that "clear and express" language is not necessary to show that the parties intended lifetime retiree health benefits. ${ }^{95}$ Such benefits can be implied from the circumstances. $^{96}$ This position challenged the majority's assertion that "when a contract is silent as to the duration of retiree benefits, a court may not infer that the parties intended those benefits to vest for life."97 The concurrence also singled out certain terms that would be relevant in determining the vesting issue. ${ }^{98}$ 1960)).

86. Id. at 936 (quoting 3A ARThur Linton CoRBin, Corbin on Contracts $\$ 553$ (2d ed.

87. $I d$.

88. Id. at 937. here.").

89. Id. ("[T]here is no doubt that Yard-Man and its progeny affected the outcome

90. Id.

91. $I d$.

92. Id.

93. Id. (Ginsburg, J., concurring).

94. Id.

95. Id. at 938 .

96. Id.

97. Id. at 937 (majority opinion).

98. Id. at 938 (Ginsburg, J., concurring) ("Because the retirees have a vested, lifetime right to a monthly pension ... a provision stating that retirees 'will receive' healthcare benefits if they are 'receiving a monthly pension' is relevant to this examina- 


\section{Problems with the Supreme Court Opinion}

The Supreme Court misunderstood "ordinary contract principles"99 and their application to the $M \& G$ dispute. It is important first to comment briefly on the Court's focus on the Yard-Man inferences. An inference arises when evidence reasonably supports the probability of the fact being proven-for example, the Sixth Circuit thought that a retirement benefit created the inference that the benefit lasts as long as the employee is retired. ${ }^{100}$ Once an inference arises, the party offering the evidence has met its burden of production and can avoid summary judgment or a directed verdict. ${ }^{101}$ A presumption, on the other hand, means that the party offering the evidence has satisfied its burden of persuasion, which shifts to the opposing party (at minimum) the burden of production on the issue. ${ }^{102}$

Much of the Supreme Court's opinion criticizes the Sixth Circuit's use of the Yard-Man inferences, but its primary objection appears to be that the Sixth Circuit used the inferences to create a presumption of lifetime retiree healthcare benefits. ${ }^{103}$ For example, the Court reversed the Sixth Circuit's affirmance of the presumption that, "in the absence of extrinsic evidence to the contrary, the agreements indicated an intent to vest lifetime contribution-free benefits." 104 The Court's criticism of Yard-Man's "thumb on the scale"105 in favor of vesting also strongly suggests that the Court thought Yard-Man and its progeny shifted the burden of proof on the vesting issue. Further, Justice Ginsburg's concurrence interpreted Justice Thomas's opinion as rejecting the Yard-Man "presumptions": "Today's decision rightly holds that courts must apply ordinary contract principles, shorn of presumptions, to determine whether retiree health-care benefits survive the expiration of a collective-bargaining agreement." ${ }^{106}$ Finally,

tion. ... So is a 'survivor benefits' clause instructing that if a retiree dies, her surviving spouse will 'continue to receive [the retiree's health-care] benefits . . . until death or remarriage.").

99. Id. at 935 (majority opinion).

100. Id. at 933 ("[T] he Court of Appeals applied the Yard-Man inferences to conclude that ... the provisions of the contract indicated an intent to vest retirees with lifetime benefits.").

101. See, e.g., Richard H. Field et al., Civil Proceddre: Matertals for a Basic Course 1328-33 (10th ed. 2010).

102. "[W] to exist in the absence of adequate rebuttal." Id. at 1340.

103. See $M \& G, 135$ U.S. at 935 . Ordinarily, the plaintiff has the burden of persuasion to prove its case. The presumption here would shift the burden of proof to $M \& G$.

104. Id. at 932. In fact, the Court used terminology such as "inference," "presumption," and "supposition" almost interchangeably throughout the opinion.

105. Id. at 935 .

106. Id. at 937 (Ginsburg, J., concurring). 
the Court singled out post-Yard-Man cases that the Court believed had taken Yard-Man too far toward a presumption of vesting. ${ }^{107}$

Understanding the Court's evidentiary language and reasoning is important to explain how the Court went wrong in applying ordinary contract principles. The Court probably was correct that the inferences together were insufficiently compelling to create a presumption that shifted the burden of persuasion to $M \&$ G. ${ }^{108}$ But the Court should not have entirely rejected the Yard-Man inferences. Instead, the Court should have explained that, as ordinary contract principles, the inferences created an issue for the trier of fact. ${ }^{109}$

Each of the Sixth Circuit's inferences was relevant to the duration of retiree healthcare benefits. Further, the inferences together, if not separately, were sufficiently probative to reach the trier of fact. This Part explains why this is so and how the Court lost its way.

\section{A. The Court's Focus on the Parties' Intentions}

Although courts interpreting contract language often invoke the "intentions of the parties" rubric, ${ }^{110}$ the reality of how they proceed is quite different. ${ }^{111}$ Courts generally enforce a reasonable interpretation of the language-an objective test-rather than an interpretation

107. Id. at 935 (majority opinion) (discussing Cole v. ArvinMeritor, Inc., 549 F.3d 1064, 1074 (6th Cir. 2008) and Noe v. PolyOne Corp., 520 F.3d 548, 555 (6th Cir. 2008)).

108. Courts create presumptions in part based on probability: "Most presumptions have come into existence primarily because the judges have believed that proof of fact $B$ renders the inference of the existence of fact $A$ so probable that it is sensible and timesaving to assume the truth of fact A until the adversary disproves it." 2 KENNETH $S$. Broun, McCormick on Evidence $\$ 343$ (7th ed. 2013). Yard-Man's reasoning alone, while probative, is not so probable that it should shift the burden of persuasion to M \& G. For example, Yard-Man's inference that retiree healthcare benefits can be a form of deferred compensation is not so probable that it calls for assuming the truth of the inference. Further, "a presumption will be superimposed on an inference in situations of special need in the proof process, such as where the opponent has unique access to evidence on the disputed fact. In [M\& $\&$ ], there is no suggestion of a need for the overkill of creating a presumption." E-mail from Kevin M. Clermont, Prof. of Law, Cornell Law Sch., to Robert A. Hillman, Prof. of Law, Cornell Law Sch., (Jan. 24, 2017, 5:15 EST) (on file with author).

109. See generally Reese v. CNH Indus. N.V., 143 F. Supp. 3d 609 (E.D. Mich. 2015). For a post-Supreme Court trial court decision in another retiree case, in which the court took this position on a motion to reconsider, see infra notes 202-06 and accompanying text.

110. Robert A. Hillman, Principles of Contract Law 287-88 (3d ed. 2014) (citing Portell v. AmeriCold Logistics, L.L.C., 571 F.3d 822, 824 (8th Cir. 2009)) (“"The cardinal principle of contract interpretation is to ascertain the intention of the parties and to give effect to that intent.' We read the contract as a whole and give the terms their 'plain, ordinary, and usual meaning.'”) (quoting Dunn Indus. Group, Inc. v. City of Sugar Creek, 112 S.W.3d 421, 428 (Mo. 2003) (per curiam)).

111. Id. at 280 (“ $[\mathrm{O}]$ ne of contract law's important goals is to facilitate freely made private agreements. It is therefore not surprising to find language in opinions that is consistent with this goal, even when courts are giving lip service to the idea when interpreting language."). 
based on what either party subjectively thinks the language means. ${ }^{112}$ "[T] he objective approach to interpretation ... measures a party's language and conduct against the test of reasonableness and sanctions careless, reckless, or purposeful misleading language by finding an obligation even if the promisor did not intend one."113 An exception occurs if the court finds that at the time of contracting both parties subjectively agreed to an objectively unreasonable meaning (for example, the parties intended 500 to mean 300). ${ }^{114}$ However, this situation is obviously unusual. Although the "intentions of the parties" slogan is not harmful if the court applies the objective test, we will see that the Supreme Court, influenced by the "intentions" language, guides future courts to apply the objective test too narrowly. ${ }^{115}$

Courts disagree on the process and kinds of evidence necessary to determine a reasonable interpretation of contract language. In some jurisdictions, the "plain meaning rule," which prohibits extrinsic evidence, ${ }^{116}$ prevails if the court determines that the language at issue is not ambiguous. ${ }^{117}$ Under this approach, the court need go no further to establish meaning than reading the disputed term. ${ }^{118}$ Courts applying the "contextual" approach, however, generally entertain extrinsic evidence to establish meaning, including preliminarily whether a writing is ambiguous. ${ }^{119}$ Further, "[t]he entire agreement . . . should be

112. See, e.g., Zell v. Am. Seating Co., 138 F.2d 641, 647 (2d Cir. 1943), rev'd, 322 U.S. 709 (1944) (per curiam) ("We ask judges or juries to discover that 'objective viewpoint'through their own subjective processes."); see also Robert A. Hillman, Contract Lore, 27 J. CORP. L. 505, 510-12 (2002).

113. HLLMAN, supra note 110, at 280; see also Judge Learned Hand's observation in Hotchkiss $v$. National City Bank, 200 F. 287, 293 (S.D.N.Y. 1911) ("A contract has, strictly speaking, nothing to do with the personal, or individual, intent of the parties. . . If, however, it were proved by twenty bishops that either party, when he used the words, intended something else than the usual meaning which the law imposes upon them, he would still be held, unless there were some mutual mistake, or something else of the sort.").

114. See, e.g., Hield v. Thyberg, 347 N.W.2d 503, 504, 508 (Minn. 1984) (\$15,000 meant $\$ 50,000$ ).

115. See infra notes 125-34 and accompanying text.

116. Extrinsic evidence includes "all writings, oral statements, and other conduct by which the parties manifested their assent, together with any prior negotiations between them and any applicable course of dealing, course of performance, or usage." E. Allan Farnsworth, Contracts 453 (4th ed. 2004).

117. See, e.g., Pioneer Peat, Inc. v. Quality Grassing \& Servs., Inc., 653 N.W.2d 469, 473 (Minn. Ct. App. 2002) (court decides on textual basis).

118. See Joshua M. Silverstein, Using the West Key Number System as a Data Collection and Coding Device for Empirical Legal Scholarship: Demonstrating the Method via a Study of Contract Interpretation, 34 J. L. \& CoM. 203, 253-61 (2016) (usefully describing textualists and contextualists).

119. See, e.g., id. at 254-55 (explaining that contextualist courts often use evidence of prior negotiations, commercial circumstances, and trade usage (among other factors) to interpret a contract). The issue arises in other interpretative contexts as well: "Several substantive principles of interpretation-such as constitutional avoidance, use of legislative history, and Cheuron-depend on an initial determination of whether a text is clear or ambiguous. But judges often cannot make that initial clarity versus ambiguity 
read together in light of all the circumstances." ${ }^{120}$ One can see that an agreement's context strongly influences courts' interpretations under the contextual approach and that the Yard-Man court favored this interpretive method. ${ }^{121}$

The debate continues over which interpretative method should prevail. Proponents of the plain meaning approach caution that courts make too many mistakes digesting extrinsic evidence, while contextualists maintain that words alone have no meaning in the absence of context. ${ }^{122}$ The distinction between these schools is less important here because the P\&I agreement in $M \& G$ lacked an express healthcare duration term. ${ }^{123}$ Thus, the plain meaning rule could not apply. The Supreme Court recognized the value of "known customs or usages," ${ }^{24}$ suggesting that the Court was not completely averse to the contextualist strategy and reasonableness test, but the opinion took a narrow view of the probative evidence.

In fact, the Court's failure to acknowledge the reasonableness test and its fruitless search for the parties' intentions led the Court to narrow the scope of probative evidence and to an impoverished view of ordinary contract principles. ${ }^{125}$ The Court said so itself. According to the Court, the Yard-Man inferences "distort[ed] the attempt 'to ascertain the intention of the parties." 126 If the Court had framed the inquiry as a test of reasonableness, however, the Court may have seen the "Yard-Man inferences" in a different light-as probative but not definitive - in a more complete contextual investigation.

Consider again the Yard-Man inferences: retiree healthcare benefits can be a form of deferred compensation; healthcare benefits likely last while the former employee is a retiree; tying healthcare benefits to pension benefits suggests that healthcare benefits vest. ${ }^{127}$ These inferences, based on the nature and purpose of CBAs, the meaning of re-

decision in a settled, principled, or evenhanded way." Brett M. Kavanaugh, Fixing Statutory Interpretation, 129 HARV. L. REv. 2118, 2118 (2016) (book review). The concurrence in $M \& G$ appears to leave the determination of whether a contract is ambiguous to the court without the aid of extrinsic evidence (a parol evidence question): "But when the contract is ambiguous, a court may consider extrinsic evidence to determine the intentions of the parties.” M \& G Polymers USA, L.L.C. v. Tackett, 135 S. Ct. 926, 938 (2015) (Ginsburg, J., concurring) (emphasis added).

120. FARNSWORTH, supra note 116 , at 453 .

121. Int'l Union v. Yard-Man, Inc., 716 F.2d 1476, 1479 (6th Cir 1983) ('The intended meaning of even the most explicit language can, of course, only be understood in light of the context which gave rise to its inclusion.").

122. Silverstein, supra note 118 , at $254-55$.

123. $M \& G, 135 \mathrm{~S}$. Ct. at 931 .

124. $I d$. at 935 .

125. Id. ("As an initial matter, Yard-Man violates ordinary contract principles by placing a thumb on the scale in favor of vested retiree benefits in all collective-bargaining agreements. That rule has no basis in ordinary principles of contract law.”).

126. Id. (quoting WILLISTON ON CONTRACTS $\S 30: 2$, supra note 72).

127. Id. at 936-37. 
tiree benefits, and the language of the CBA as a whole, were at least relevant under ordinary contract principles. ${ }^{128}$ For example, basic economic theory assumes that rational economic actors engaged in bargaining make trade-offs to maximize their returns. This supports the deferred compensation argument that the union may have bargained for non-mandatory lifetime healthcare benefits in exchange for less immediate compensation, regardless of the technical ERISA definitions the Court noted. ${ }^{129}$ Similarly, tying one benefit, silent on duration, to a lifetime benefit is at least probative of whether the former also lasts a lifetime. And it should be remembered that an inference is not a presumption, it only means that the dispute should survive dismissal and permit a decision by the trier of fact.

The Supreme Court should not have objected that the Sixth Circuit's Yard-Man inferences in Tackett I and II did not come from the record. Although the record contained the text of the CBA that was silent on the duration of healthcare benefits, it included other probative language on duration. ${ }^{130}$ By its very nature, purpose, and language, such an agreement has implications, including the Yard-Man inferences, which a court should consider even if the implications are insufficient to shift the burden of proof. ${ }^{131}$

To clarify, it may be helpful to consider other inferences and presumptions arising solely from the nature of the transaction. For example, in the absence of time-for-payment provisions, courts in construction cases find a duty to pay only after substantial performance. ${ }^{132}$ More generally, absent a term defining the order of performance, the party whose performance takes longer usually must perform first. ${ }^{133}$ In sales-of-goods agreements, "tender of payment is a condition to the seller's duty to tender and complete any delivery."134

128. Id. at 936.

129. See Tackett v. M \& G Polymers USA, L.C.C., 561 F.3d 478, 489 (6th Cir. 2009) ("B] $[\mathrm{B}]$ ccause retirement health care benefits are not mandatory or required to be included in an agreement, and because they are 'typically understood as a form of delayed compensation or reward for past services,' it is unlikely that they would be 'left to the contingencies of future negotiations.'”) (quoting Yolton v. El Paso Tenn. Pipeline Co., 435 F.3d 571, 580 (6th Cir. 2006) (quoting Int'l Union v. Yard-Man, Inc., 716 F.2d 1476, 1481-82 (6th Cir. 1983))).

130. $M \& G, 135 \mathrm{~S}$. Ct. at $936-37$.

131. The parties in $M \& G$ bargained in the shadow of Yard-Man and other decisions finding lifetime retiree healthcare benefits. The Court did not discuss whether the holding in those cases alone should have raised an inference or even a presumption in favor of the plaintiffs on the theory that the parties likely intended to incorporate the holdings in their agreement. The nature of the bargaining in $M \& G$, namely the lack of negotiating clarity, discussed infra notes 143-64, and the considerable differences in the language of the CBA in each case, which are the primary factors for determining intent, suggest otherwise.

132. See, e.g., Stewart v. Newbury, 115 N.E. 984, 985 (N.Y. 1917).

133. See Edwin W. Patterson, Constructive Conditions in Contracts, 42 Colum. L. REv. 903, 919 (1942).

134. U.C.C. § 2-511(1) (Aм. LAW Inst. \& UNIF. LAW Comm’n 1994). 
As previously noted, the Supreme Court apparently found the Yard-Man inferences insufficiently persuasive to form a presumption and to shift the burden of proof to M \& G. However, the Court should not have taken the inferences off the table.

\section{B. The Court's Arbitrary Identification of "Ordinary Contract \\ Principles"}

The Supreme Court selectively identified the "ordinary contract principles" the Sixth Circuit should have applied in Tackett I and II. Compare what the Supreme Court treated as disqualified Yard-Man inferences ${ }^{135}$ to those the Court found acceptable. For example, the Court said that a "written agreement is presumed to encompass the whole agreement of the parties." ${ }^{136}$ Further, promises silent on duration "will ordinarily be treated . . . as 'operative for a reasonable time." 137 In addition, "traditional rules of contractual interpretation require a clear manifestation of intent before conferring a benefit or obligation." 138 And finally, "when a contract is silent as to the duration of retiree benefits, a court may not infer that the parties intended those benefits to vest for life." 139

The Court's set of "ordinary contract principles" is too general and abstract to be useful. The presumption that a written agreement encompasses the entire agreement does not further analysis if the entire agreement is ambiguous, contradictory, or silent on the disputed issue. ${ }^{140}$ Further, the "whole-agreement" argument ignores the fact that the Sixth Circuit derived the Yard-Man inferences directly from the agreement. Further, a "reasonable" duration depends, at least in part, on the type of agreement, its purpose, and its circumstances. Thus, a "reasonable" duration can sometimes contemplate a lifetime. The clear-manifestation-of-intent principle is so broad that it is useless. Taken literally, any contract ambiguous or silent on a "benefit or obligation" would never be enforceable. The prohibition against inferring benefits for life when the contract is silent, although more specifically tied to the issues in $M \& G$, is overbroad because it would seemingly bar all retiree claims from ever reaching the fact finder.

135. See supra notes $73-98,129$, and accompanying text.

136. M \& G Polymers USA, L.L.C. v. Tackett, 135 S. Ct. 926, 936 (2015).

137. Id. (quoting CORBIN ON CoNTRACTS $\$ 553$, supra note 86). 1983).

138. Id. (quoting Int'l Union v. Yard-Man, Inc., 716 F.2d 1476, 1481 n.2 (6th Cir

139. Id. at 937.

140. The Court complained that post-Yard-Man decisions created a default vesting rule that "distort[ed] the text of the agreement and conflict[ed] with the principle of contract law that the written agreement is presumed to encompass the whole agreement of the parties." Id. at 936. But how the "whole agreement" treated duration of a retiree benefit was the issue in the case. A default rule one way or the other would therefore not conflict with the "whole agreement" rule. 
Such rules of interpretation are not helpful in reaching a reasonable interpretation of the P\&I.

Significantly, the Court omitted several relevant interpretive "principles" similar to those it did discuss, such as ambiguous language is interpreted against the drafter; parties intend common, not unusual, meanings of language; specific language takes precedence over general language; and interpretation that upholds a contract is preferred. ${ }^{141}$ The problem with these so-called rules and the ones the Court singled out is that one suspects courts utilize them predominantly to support decisions reached on other, more specific grounds. If these general rules contradict a court's preferred decision, courts ignore them or apply a readily available counter-rule. ${ }^{142}$ However, such rules should not be ignored. Instead, they should be treated precisely as the Supreme Court should have treated the Yard-Man inferences-as one of several tools to determine the meaning of language.

\section{M \& G Is Better Analyzed as a Gap Case}

The trial court's summation of the plaintiffs' pertinent testimony and the evidence revealed in the various decisions demonstrate that the parties never reached agreement on the duration of retiree healthcare benefits. ${ }^{143}$ The search for the "intentions of the parties" was therefore bound to fail. ${ }^{144}$

Testimony highlighted at retrial after Tackett I centered on whether the side letters that capped benefits and required retiree contributions were enforceable as part of the agreement, rather than on the meaning of the agreement itself. ${ }^{145}$ However, the trial court's discussion of the testimony reveals the extent to which negotiations were

141. Tackett III points out that "[t] he Court did not purport to discuss all of the ordinary principles of contract law." Tackett v. M \& G Polymers USA, L.L.C., 811 F.3d 204, 208 (6th Cir. 2016).

142. The use of rules and maxims in interpretation "is often more ceremonial (as being decorative rationalizations of decisions already reached on other grounds) than persuasive (as moving the court toward a decision not yet reached) . . . . Indeed, a court can often select from among pairs of opposing or countervailing rules that seem to conflict ...." FARNSWORTH, supra note 116, at 456-57; see also Edwin W. Patterson, The Interpretation and Construction of Contracts, 64 CoLuM. L. REv. 833, 852 (1964).

143. This is apparently very often the case in retiree-benefit negotiations. "[F]or the Sixth Circuit to be concentrating on intent evidence seems disingenuous. In most circumstances neither party considered the issue, thus making the search for evidence of intent an elusive one." Rogers, supra note 15 , at 1054 . Counsel for petitioner in the oral argument before the Supreme Court seemed to concede as much in arguing that the Court must look to "the operative default rules that-that we assume that if the parties didn't contract around." Transcript of Oral Argument at 8-9, $M \& G, 135$ S. Ct. 926 (No. 13-1010).

144. In fact, the Supreme Court sometimes accepts this fact by trying to determine what to do "when a contract is silent as to the duration of retiree benefits . . ." $M \& G$, 135 S. Ct. at 937.

145. See Tackett v. M \& G Polymers USA, L.L.C., 853 F. Supp. 2d 697, 703-09 (S.D. Ohio 2012). 
ill-informed and haphazard. For example, union workers and officials testified to being unaware "of any employer contribution limit or cap"146 and believed the union "never intended to have retirees pay a premium." 147 M \& G's human resources director testified "that he was not trained in benefits administration and that he [had] only a basic understanding of ERISA requirements." 148 According to the director, $M$ \& $G$ had never sent the requisite ERISA notice to retirees concerning possible benefit termination. ${ }^{149} \mathrm{M} \&$ G's lawyer, in turn, testified that he relied on the untrained director "to be the primary architect" for the agreement. ${ }^{150}$ Further, the lawyer testified "he never did any research" concerning the side letters' applicability and "he had never read the 2000 P\&I agreement cover to cover." 151 At one point, the lawyer stated the side letters did not apply. ${ }^{152}$ The trial court concluded:

The factual history that the parties present could not be more different .... [T] he parties' decade-plus history of dealing with the cap letters and contributions does not present a model of negotiating clarity, much less competence .... . [T] he significant confusion by the parties is odd .... [E]ven key actors were confused by what essentially hidden agreements applied in what context .... This is no way to run a business or a union .... [I]nvestors should know what company liabilities exist, unions at all levels should be clear on what they are negotiating, and retirees should know what agreements they are ratifying. ${ }^{153}$

Contradictory language in the agreement, as well as M \& G's effort to prove the side letters were part of the agreement, also demonstrate that the parties did not agree on the duration issue. ${ }^{154} \mathrm{Ex}$ hibit B-1, referenced in the P\&I, included the following introductory language: "Effective January 1, 1998, and for the duration of this Agreement thereafter, the Employer will provide the following program of hospital benefits, hospital-medical benefits, surgical benefits and prescription drug benefits for eligible employees and their dependents ...." ${ }^{155}$ By tying the benefits to the existing three-year CBA, the

146. Id. at 703-04.

147. $I d$. at 705 .

148. Id. at 708. The trial court called the director "curiously under-informed." Id. at 718 .

149. Id. at 708 .

150. Id. at 709 .

151. Id.

152. Id. at 717 .

153. Id. at $715,717-18$. A more charitable explanation for the duration gap is that the parties feared that pursuing the duration issue would defeat the agreement, but the facts recited in the various opinions do not support this explanation.

154. Id. at 719-20.

155. M \& G Polymers USA, L.L.C. v. Tackett, 135 S. Ct. 926, 931 (2015). Of course, Exhibit B-1 may mean only that the particular description of the benefits lasts for duration of the CBA. 
"duration" language suggests that the benefits would only last for three years. As referenced by the Supreme Court concurrence, other language, however, suggests that the healthcare benefits would last for the retirees' lifetime:

Because the retirees have a vested, lifetime right to a monthly pension ... a provision stating that retirees "will receive" health-care benefits if they are "receiving a monthly pension" is relevant to this examination. . . . So is a "survivor benefits" clause instructing that if a retiree dies, her surviving spouse will "continue to receive [the retiree's health-care] benefits ... until death or remarriage." 156

Recall, also, that M \& G sought to prove that the side letters requiring contributions and capping benefits were part of the agreement. ${ }^{157}$ This suggests $M \& G$ did not believe the P\&I agreement alone reached those issues. Instead, M \& G's effort shows it sought, but failed, to cap benefits. ${ }^{158}$

At oral argument, Justice Alito asked why the bargainers left the CBA silent on the duration of healthcare benefits. ${ }^{159}$ In the absence of a satisfactory answer by respondents, Justice Scalia remarked, "I mean, this thing [the duration issue] is obviously an important feature. Both sides knew it was left unaddressed, so, you know, whoever loses deserves to lose for casting this upon us when it could have been said very clearly in the contract. Such an important feature."160 In addition to Justice Scalia's and the trial court's intimation that incompetence was the answer, ${ }^{161}$ both sides may have had a strategic reticence to raise the issue. Union and management lawyers familiar with collective bargaining, particularly on vesting of healthcare benefits, concede they are willing to live with uncertainty because of the dangers of even raising the issue during bargaining. ${ }^{162}$ The union worries that if it raises the issue, but fails to get the company to agree to vesting, the CBA, by implication, will not include lifetime benefits. ${ }^{163}$ This is so even if the union tries to clarify that it is only seeking an express provision for what it believes is implicit, namely, lifetime benefits. Simi-

156. Id. at 938 (Ginsburg, J., concurring)

157. Tackett, 853 F. Supp. $2 d$ at 715.

158. Id. ("Defendants have engaged in after-the-fact company scrambling to find a way to impose unilaterally application of cap letters as a cost-savings measure that defies the agreements the caps puncture.").

159. Transcript of Oral Argument at 18, $M$ \& $G, 135$ S. Ct. 926 (No. 13-1010).

160. Id. at 22 .

161. See supra notes $146-53$ and accompanying text.

162. Responses to inquiries from the author. The lawyers preferred to remain anonymous. See also Jonathan Kane, We Have to Give Them What? Negotiating the First Contract from the Employer's Perspective, at 10, 2010 A.B.A. SEC. LAB. \& EMP. LAw CoNF, http://www.americanbar.org/content/dam/aba/administrative/labor_law/ meetings/2010/annualconference/180.authcheckdam.pdf (demonstrating how healthcare negotiations during collective bargaining can lead to notable concessions).

163. Tackett, 853 F. Supp. $2 d$ at 715. 
larly, the company does not want to bargain for the expiration of healthcare benefits because, if it fails to get agreement, the implication will be that benefits vest. Each side may be content to rely on context and the implication of other terms in the CBA to establish its view of the healthcare benefits duration.

One can conclude that the parties here, and likely others in many additional cases involving disputes over the duration of retiree healthcare benefits, failed to reach agreement because of strategic decisionmaking and rather inept bargaining and drafting. ${ }^{164}$ Therefore, under ordinary contract principles, the $M \& G$ Court should have focused neither on finding "the intentions of the parties" nor how to treat ambiguous language. Instead, the Court should have determined how to fill the contract duration gap.

Courts do not enforce contracts with a material gap or multiple gaps. ${ }^{165}$ In large part, this ordinary contract principle results from courts' inability to fashion a remedy if an important term, such as the price of goods or the subject matter of an agreement, is missing. ${ }^{166}$ Nevertheless, another ordinary contract principle allows courts to supply a missing contract term if the parties intended to contract and the gap or gaps are not too severe. ${ }^{167}$ Clearly, the parties in $M \& G$ intended to contract, and the missing duration term should not invalidate the entire agreement. ${ }^{168}$

Courts employ a diversity of gap filling techniques. One approach considers "what the parties would have done" to align the court's decision most closely with the principle of freedom-of-contract. This approach also reduces the costs of contracting by creating a default rule that eliminates the need for future bargaining over that

164. See Rogers, supra note 15, at 1046 (discussing Int'l Union v. Cadillac Malleable Iron Co., No. G82-75-CA1, 1982 WL 20483, at *4 (W.D. Mich. Apr. 28, 1982) ("the court acknowledged that the duration of retiree benefits had never been discussed during contract negotiations .....")).

165. See, e.g., Champaign Nat'l Bank v. Landers Seed Co., 519 N.E.2d 957, 959-60 (Ill. App. Ct. 1988) ("The terms of a contract must be reasonably certain. Some terms may be missing or left to be agreed upon, but if the essential term or terms are so uncertain that there is no basis for deciding whether the agreement has been kept or broken, there is no contract.").

166. Restatement (Second) of Contracts $\S 33$ (Am. Law Inst. 1981) ( ${ }^{“}[R]$ emedies for breach of contract must have a basis in the agreement of the parties.").

167. Zielinski v. Pabst Brewing Co., 463 F.3d 615, 619-20 (7th Cir. 2006) ("Filling gaps is a standard activity of courts in contract cases.").

168. Sometimes it is difficult to determine whether a court has filled a gap after concluding that the parties never reached agreement on an issue or the court has interpreted an agreement objectively. The Yard-Man and Tackett Sixth Circuit decisions are good examples. One explanation of the court's rationale in such decisions is that, according to a reasonable interpretation of the agreement, the retiree healthcare benefits vested. Another explanation of the rationale, however, is that the court supplied the duration term for the parties as a matter of gap-filling. The line is fine between the two processes and rarely should affect outcomes, although courts filling gaps may feel more freedom to innovate. 
term. ${ }^{169}$ Although courts struggle in determining what the parties would have preferred, this approach may be the most prominent gap filler. ${ }^{170}$

Another judicial gap-filling tool is establishing a "penalty default" to incentivize information sharing between contracting parties. For example, the famous case of Hadley $v$ Baxendale, ${ }^{171}$ involving delay in the carriage of a miller's broken crank shaft, is an example of a "penalty default," that

penalizes the miller for failing to reveal the ramifications of tardy delivery (the loss of profits). The miller's penalty is that it cannot recover the lost profits. Further, were it not for the Hadley rule, the miller would have an incentive not to disclose. The information would lead the carrier to raise its price of carriage because it would be taking a greater risk (assuming that most millers do not suffer lost profits due to a carrier delay). In sum, penalty-default theorists assert that Hadley creates incentives for the miller to reveal information and for the carrier to select the appropriate level of precaution. ${ }^{172}$

Of course, identifying efficient gap-fillers is often challenging for courts. Cases on the duration of retiree healthcare benefits are no exception. A gap-filler that healthcare benefits vest could discourage employers from offering healthcare plans at all, especially as healthcare costs rise. ${ }^{173}$ However, promises of retirement security help companies recruit and maintain a dedicated, efficient workforce. Retirement security also keeps retirees out of public assistance programs. ${ }^{174}$

Courts should also consider how to incentivize companies and unions to draft express duration clauses that avoid costly litigation. Unfortunately, courts faced with the duration issue have not sought to motivate parties in this direction. ${ }^{175}$ Perhaps too many companies have relied on the "default rule" that "contractual obligation will cease, in the ordinary course, upon termination of the bargaining

169. Hillman, supra note 110, at 293-94 (citing Richard Posner, Economic ANalysis of LAW 96-98 (7th ed. 2007).

170. See id. at 293-94 for additional discussion.

171. (1854) 156 Eng. Rep. 145.

172. Hnlman, supra note 110, at 295; see also id. at 180-81 (discussing Ian Ayres \& Robert Gertner, Filling Gaps in Incomplete Contracts: An Economic Theory of Default Rules, 99 YALE L.J. 87 (1989)).

173. See generally Christine Eibner \& M. Susan Marquis, Employers' health insurance cost burden, 1996-2005, MONTHLY LAB. REv. 28-44 (June 2008), https://www.bls.gov/ opub/mlr/2008/06/art3full.pdf.

174. Tackett v. M \& G Polymers USA, L.L.C., 853 F. Supp. 2d 697, 710 (S.D. Ohio 2012) (" $[I] t$ is in the public interest to transfer the burden of coverage to the private company that included such coverage in its bargaining and not to keep much of the burden of providing health care coverage on the public by forcing numerous retirees and their dependents to rely upon public assistance programs.").

175. See generally Rogers, supra note 15, for a discussion of cases following YardMan; see also infra notes 196-212 and accompanying text for cases after $M \& G$. 
agreement." 176 This strategy is risky because it requires parties to predict whether their circumstances fit into the "ordinary course."177

A third gap-filling tool is for courts to construct what they believe is a fair gap-filler. Courts may consider the case's equities, including bargaining power, wrongful conduct, and the potential gains and losses of each party, with the goal to ensure that each party receives its fair bargain. ${ }^{178} \mathrm{~A}$ court here seeks to avoid creating a windfall for one party and a catastrophe for the other. ${ }^{179}$

In light of this discussion, re-consider Tackett II. On the one hand, the Sixth Circuit found the retirees were entitled to lifetime healthcare benefits, but on the other, it held that the retirees would receive these benefits subject to "reasonable changes" in costs. ${ }^{180}$ The court observed that such changes were necessary to accommodate increased healthcare costs. ${ }^{181}$ "Reasonable changes," however, would not reduce benefits to zero. ${ }^{182}$ The court took both parties' interests into account and arguably provided the fairest solution, especially compared to other gap-filling techniques. Of course, determining what constitutes "reasonable changes" may challenge courts in some cases. ${ }^{183}$

Precedent exists for such a compromise in other contexts. For example, in Haines $v$. City of New York, ${ }^{184}$ the city had agreed with certain villages that were polluting streams forming part of the city's water supply to build and maintain a sewage treatment facility. ${ }^{185} \mathrm{De}-$ cades later, the municipalities sued, alleging the agreement required the city to expand the facility to accommodate the unanticipated dramatic increase in the need for sewer lines caused by the municipalities' population growth. ${ }^{186}$ The New York Court of Appeals reached a compromise, holding that the city was obligated to maintain the plant, but not to expand the facility. ${ }^{187}$ The court did not perpetually bind the city to accommodate population increases, nor did it find the agreement terminable at the city's will. ${ }^{188}$ The court thus filled the gap by fashioning an equitable solution. ${ }^{189}$

176. Litton Fin. Printing Div. v. NLRB, 501 U.S. 190, 207 (1991).

177. See infra notes 190-201 and accompanying text.

178. HILLAN, supra note 110 , at 296-97.

179. Id. at 296.

180. Tackett v. M \& G Polymers, USA, L.L.C., 733 F.3d 589, 600-01 (6th Cir. 2013).

181. Id. at 601 .

182. Id. at $600-01$. 2015),

183. See, e.g., Reese v. CNH Indus. N.V., 143 F. Supp. 3d 609, 626-30 (E.D. Mich.

184. 364 N.E.2d 820 (N.Y. 1977).

185. Id. at 821 .

186. Id. at 821-22.

187. Id. at 822 .

188. Id. at 822-23.

189. Id.; see also City of Yonkers v. Otis Elevator Co., 844 F.2d 42, 47-49 (2d Cir. 1988); RESTATEMENT OF EMPLOYMENT LAW $\S 2.06$ (AM. LAw INST. 2015) (“An employer may prospectively modify or revoke its binding policy statements if it provides reasonable ad- 


\section{The Sixth Circuit's Challenge on Remand}

The Sixth Circuit faced a challenge on remand. Part of the problem, as already noted, was the Supreme Court's lack of clarity on whether it objected to the Yard-Man inferences as together forming a presumption of lifetime benefits or objected to each inference individually. ${ }^{190}$ Put another way, was there any role left for contextual evidence concerning the now-defunct inferences? What exactly did the Court mean by stating that the Sixth Circuit wrongly allowed YardMan inferences to "put a thumb on the scale"?

Another issue was what portions of the Yard-Man reasoning depended upon rejected "inferences?" For example, Yard-Man contrasted the many duration terms in the CBA concerning such things as insurance and family benefits with the absence of a retiree healthcare duration term. ${ }^{191}$ According to the Sixth Circuit, this suggested the duration of retiree healthcare benefits should be treated differently from the terminable insurance and family benefits. ${ }^{192}$ The Supreme Court did not expressly reject this reasoning. Yard-Man also pointed to management's course of dealing, suggesting that retiree healthcare benefits vested: 'Yard-Man's own course of conduct in continuing retiree insurance benefits after plant closure beyond the point at which insurance benefits could have been terminated for active employees indicates that it did not consider retiree benefits to be tied to the durational limitations of that active group." 193 This was also not discussed by the Supreme Court.

A third issue was whether the Court's rejection of the Yard-Man inferences meant the lower courts would have to revisit the side letters' legal significance. A close reading of the district court's description of trial testimony suggests the district court correctly disposed

vance notice of, or reasonably makes accessible, the modified statement or revocation to the affected employees.").

190. See M \& G Polymers USA, L.L.C. v. Tackett, 135 S. Ct. 926, 934-35 (2015); see also supra text accompanying notes 103-07.

191. Int'l Union v. Yard-Man, Inc., 716 F.2d 1476, 1481 (6th Cir. 1983).

192. Id.

[T] he insurance provisions limit health insurance coverage for a retiree's spouse and dependent children in case of the retiree's death to expiration of the collective bargaining agreement. While this limitation does not preclude an intent to also terminate the retiree's benefits with the expiration of the collective bargaining agreement in any event, it is more reasonable to infer that the spouse-dependent child provision was meant as an exception to the anticipated continuation of benefits beyond the life of the collective bargaining agreement.

Id.

193. Id.; see also Rogers, supra note 15, at 1047-48 (the company in Cadillac Malleable Iron "had always paid insurance benefits to retirees during strikes . . . ."). 
of this issue, ${ }^{194}$ but $M \& G$ argued that the decision was made in the "shadow of Yard-Man" and should be revisited. ${ }^{195}$

Following the Supreme Court's decision, the Sixth Circuit in Tackett III remanded the case to the district court for the third time. ${ }^{196}$ The Sixth Circuit thought it was unclear whether the district court's earlier side letter decision had been influenced by Yard-Man. ${ }^{197}$ Therefore, the trial court had to determine once again "whether the [side] letters, or other documents, are part of the Agreement or may otherwise serve as extrinsic evidence." 198 The Sixth Circuit directed the district court to "use ordinary principles of contract law" to assess whether the side letters were part of the CBA, whether to entertain extrinsic evidence, and, ultimately, whether the retiree healthcare benefits vested. ${ }^{199}$

The questions raised by the Supreme Court's decision-was the Court rejecting the inferences because together they created a presumption? What Yard-Man reasoning, if any, survived the opinion?were not resolved by the Sixth Circuit's remand instructions to the district court. In effect, the Sixth Circuit largely punted, with one exception. Tackett III appears to recognize the limited role of the agreement's general duration clause:

[W] hile the Supreme Court's decision prevents us from presuming that "absent specific durational language referring to retiree benefits themselves, a general durational clause says nothing about the vesting of retiree benefits," we also cannot presume that the absence of such specific language, by itself, evidences an intent not to vest benefits or that a general durational clause says everything about the intent to vest. ${ }^{200}$

In other words, absent a specific term on the duration of healthcare retiree benefits, a general duration clause is merely probative evidence. ${ }^{201}$

Two additional post- $M \& G$ cases also illustrate the confusion wrought by the Court. In Reese v. CNH Industrial N.V., ${ }^{202}$ still another case involving the duration of retiree healthcare benefits, the district court first held that $M \& G$ required the court to reverse a previous

194. Tackett v. M \& G Polymers USA, L.L.C., 811 F.3d 204, 210 (6th Cir. 2016) (hereinafter Tackett III) ("On its face, the district court determined, independent of Yard-Man or its inferences, that the cap letters were not part of the Agreements.").

195. Id.

196. Id.

197. $I d$.

198. Id. As discussed previously, supra notes 58-60 and accompanying text, $M \&$ G's efforts to show that the side letters limited the plaintiffs' healthcare rights suggested that $M \& G$ did not believe that the P\&I agreement alone did so.

199. Tackett III, 811 F.3d at 210 .

200. Id. at 209; see also Gallo v. Moen Inc, 813 F.3d 265, 268 (6th Cir. 2016) (relying in part on a general duration term).

201. Tackett III, 811 F.3d at 209.

202. 143 F. Supp. 3d 609 (E.D. Mich. 2015). 
district court decision in favor of retirees. ${ }^{203}$ On reconsideration, however, the district court held that it had been "too hast[y]" and that the Supreme Court did not intend to "require clear and express vesting language to find the parties' intent to vest." ${ }^{04}$ The court specifically responded to whether there was any role left for contextual evidence related to the former inferences:

[This] [c]ourt erred in reading Tackett as "suggest[ing] that courts should not rely on language tying eligibility for contribution-free healthcare benefits to the receipt of pension benefits." All that Tackett holds or suggests is that a court may not infer from such tying language that the parties intended retiree health insurance benefits to vest. Such language does not lose all significance, however. In other words, Tackett does not hold that courts must ignore language that under Yard-Man and its progeny inferred an intent to vest. To the contrary, Tackett advises courts to apply "ordinary principles of contract law"; and under those principles, "the intention of the parties" is "gathered from the whole instrument . . . ."205

Based on this reasoning, among other things, the court reinvigorated the argument tying healthcare benefits to vested pension benefits and the assertion that the general duration clause "does not dictate automatically that the agreement's general durational clause applies" to retiree benefits. ${ }^{206}$

In Gallo v. Moen Inc. ${ }^{207}$ however, the Sixth Circuit reversed a trial court holding in favor of vested retiree healthcare benefits based on the Supreme Court's "repudiation" of Yard-Man and its progeny. ${ }^{208}$ The opinion reads as if the Yard-Man inferences no longer have any place in a decision on vesting and refers to the general duration term as a default rule that controls "[i]n the absence of specific language in the retiree healthcare provisions." 209 A strong dissent thought the majority placed "a thumb on the employer's scale" 10 by ignoring the context, including the "reality" first discussed in YardMan that negotiations involve "give and take" over salary and benefits. ${ }^{211}$ The dissent thought the Yard-Man inferences remained alive and well as probative evidence of the meaning of the CBA. ${ }^{212}$

203. Id. at 610 .

204. Id. at 612 .

205. Id. at 613 (internal citation omitted).

206. Id.

207. 813 F.3d 265 (6th Cir. 2016).

208. Id. at 267.

209. Id. at 271-72.

210. Id. at 275 (Stranch, J., dissenting).

211. Id. at 277.

212. The Supreme Court declined to hear an appeal of this case. Gallo v. Moen, Inc., 813 F.3d 265 (6th Cir. 2016); see also Sloan v. Borgwarner, Inc., No. 09-cv-10918, 2016 WL 7107228, at *12-13 (E.D. Mich. Dec. 5, 2016). 


\section{Conclusion}

An analysis of the $M \& G$ case leads to the following conclusions. First, despite the Supreme Court's criticism of Yard-Man, no one should doubt that the Yard-Man strategy of interpretation (as opposed to the conclusions reached) reflects ordinary contract principles. In the absence of an express term, the Yard-Man approach mandates a close look at the contract and its circumstances. ${ }^{213}$

Second, the important, but unresolved, controversy over whether the textual or contextual approach to interpretation best reduces the cost of contracting is not relevant here. None of the decisions examined here maintained that the P\&I agreement expressly determined the vesting issue. A contextual investigation was inevitable.

Third, under these circumstances, the Court should have remanded the case to the Sixth Circuit without rejecting the YardMan inferences, but with instructions that the inferences do not create a presumption in favor of vesting. ${ }^{214}$ Put another way, the inferences, at least along with other evidence such as the trial testimony, were sufficient to get the case to the trier of fact, but not to create a presumption in favor of vesting.

Fourth, the Court should have instructed the Sixth Circuit that if a reasonable interpretation of the evidence demonstrated that the parties never reached agreement on the vesting issue, the court must fill the gap. A good argument can be made that the most acceptable gapfiller was the Sixth Circuit's equitable solution in Tackett II that the retirees' healthcare benefits lasted their lifetimes, but could be reasonably adjusted based on circumstances, such as the costs of providing the benefit and the company's balance sheet. ${ }^{215}$ This approach, notwithstanding its complexity, would balance the uncertainties confronting businesses with the concerns of retirees who must "fear[] the loss of their family's healthcare coverage." 216

Unfortunately, the Supreme Court's attempt to clarify the Sixth Circuit's treatment of the duration of retiree healthcare benefits failed. More litigation is likely inevitable in retiree healthcare benefits cases and beyond because, in truth, $M \& G$ is "both an example" of the interpretation and gap filling quagmire "and a perpetuation of it." ${ }^{217}$ The

213. See supra note 121 and accompanying text.

214. In the $M \& G$ oral argument before the Supreme Court, respondents were apparently content with a remand: "[I]f the Court wants to be sure that the judgment below is, in fact, based on normal principles of contract interpretation, we are perfectly comfortable with a remand for that purpose." Transcript of Oral Argument at 26, M \& G Polymers USA, L.L.C. v. Tackett, 135 S. Ct. 926 (2015) (No. 13-1010).

215. Tackett v. M \& G Polymers, USA, L.L.C., 733 F.3d 589, 600-01 (6th Cir. 2013).

216. Gallo, 813 F.3d at 277.

217. David Hoffman pointed this out after reading a draft of this article. E-mail from David A. Hoffman, Prof. of Law, U. of Pa. Law Sch., to Robert A. Hillman, Prof. of Law, Cornell Law Sch., (Aug. 12, 2016, 3:41 EST) (on file with author). For an article 
$M \& G$ case should also alert lawyers who are considering an important issue at the bargaining stage to be more cognizant of the likely litigation costs of declining to raise the issue and to include an express term in the agreement. ssrn.com/sol3/papers.cfm?abstract_id=2865752. 